\title{
NEGOTIATING THE SPACE FOR PEACE: Interreligious Tolerance and Harmony in Practice
}

\author{
Muhammad Saifullah Rohman \\ Research Center for Society and Culture \\ Indonesian Institute of Sciences, Jakarta, Indonesia \\ Email: saifullah.rohmanoI@gmail.com
}

\begin{abstract}
Nowadays, Indonesia well known as tolerance country has been facing a severe problem with the practice of intolerance act and radicalism. Recently, we were shocked by some news about a young man attacking St. Lidwina Bedog church, Yogyakarta, and the suicide bombing at three churches in Surabaya. Several innocent civilians became the victim from these actions. Besides, we can note that there was another intolerant act regarding the building of a house of worship and conflict among religious believers in some district in Indonesia. These situations indicated that actors who attempted to destroy Indonesia's unity through harmful narratives of Indonesian diversity and threaten Indonesian tolerance are ranging from ethnicity, language, to religion. This article proposes a counter-narrative for Indonesian harmony by identifying the places of house of worship and spaces of religious tolerance activities. Since the establishments of the house of worship in several places have led to a disharmony and intolerance act, this article found another story of tolerance based on a house of worship location and space of tolerance activity. Field research was conducted in Balun Village, Lamongan, where three houses of worship built neighboring in the village. These neighboring houses of worship and religious activities around support the idea called "negotiating the space of peace." The data collection methods included participant observation and interview. The findings show that religious diversity of Indonesian citizens is based on unity and peace. The neighboring houses of worships (Mosque, Church, Pura/ Hinduism temple, etc.) in Lamongan, show that the tolerance among different religious believers has been there as long as Indonesian history. It is not only the negotiation in terms of physical space where the house of worship built but also non-physical space among religions and their believers, which build and strengthen the peace among them. Therefore, the peace situation and condition become the central point regardless of their background (ethnicity, religions, and language).
\end{abstract}

Keywords: Negotiation, Space, Inter-religious Tolerance, House of Worship, Narration, Peace and Harmony

\section{Abstrak}

Saat ini, Indonesia yang dikenal sebagai negara toleransi menghadapi masalah serius dengan praktik tindakan intoleransi dan radikalisme. Baru-baru ini, kami dikejutkan oleh beberapa berita tentang penyerangan gereja di gereja St. Lidwina Bedog, Yogyakarta oleh seorang pemuda dan pemboman bunuh diri tiga gereja di Surabaya. Beberapa warga sipil tak berdosa menjadi korban dari tindakan itu. Selain itu, kita juga dapat mencatat bahwa ada tindakan intoleran lain mengenai pembangunan rumah ibadat dan konflik di antara umat beragama yang terjadi di beberapa kabupaten di Indonesia. Situasi ini menunjukkan bahwa para aktor yang berupaya menghancurkan persatuan Indonesia melalui narasi buruk tentang keanekaragaman Indonesia, mulai dari etnis, bahasa, hingga 
agama, mengancam toleransi Indonesia. Artikel ini mengajukan kontra narasi tentang kerukunan Indonesia dengan mengidentifikasi tempat ibadah dan ruang kegiatan toleransi beragama. Karena pembangunan rumah ibadah di beberapa tempat mengarah pada ketidakharmonisan dan tindakan intoleransi, artikel ini menemukan cerita toleransi lain berdasarkan lokasi rumah ibadah dan ruang kegiatan toleransi. Penelitian lapangan dilakukan di Desa Balun, Lamongan di mana tiga rumah ibadah dibangun bertetangga di desa itu. Rumah ibadah dan kegiatan keagamaan di sekitarnya yang bertetangga ini mendukung gagasan yang saya sebut sebagai "menegosiasikan ruang damai”. Metode penelitian termasuk observasi partisipan dan wawancara. Temuan penelitian menunjukkan bahwa keragaman agama warga negara Indonesia adalah basis persatuan dan perdamaian. Rumah ibadat tetangga (Masjid, Gereja, Pura, dll.) Di Lamongan menunjukkan toleransi di antara para penganut agama yang berbeda selama sejarah Indonesia. Bukan hanya negosiasi dalam hal ruang fisik di mana rumah ibadah dibangun, tetapi juga ruang non-fisik di antara agama dan orang percaya mereka, yang membangun dan memperkuat perdamaian di antara mereka. Oleh karena itu, situasi dan kondisi perdamaian menjadi titik sentral dalam hubungan masing-masing tidak peduli apa latar belakang mereka (etnis, agama, dan bahasa).

Kata Kunci: Negosiasi, Ruang, Toleransi Antaragama, House of Worship, Narration, Peace and Harmony

\section{INTRODUCTION}

Bhinneka Tunggal Ika or "unity in diversity" is the Indonesia motto that ties up and bonds all citizens to be one Indonesian people. Although Indonesia consists of different local languages, ethnics, and religions, it is not a source of social cleavage. It is a source of Indonesian unity as a nation. The motto is supported by the practice of tolerance among Indonesian citizens. However, this situation goes on with some obstacles. Several practices of intolerance and conflicts have happened in several places in Indonesia, such communal conflict in Ambon and the recent suicide bombing in Surabaya by terrorists. Some intolerant incidents somehow became a threat to Indonesian unity among the citizens.

Meanwhile, the idea and formulation of Islamic Shari'a. ${ }^{17}$ As a solution proposed by some actors cannot be the sole way to solve Indonesian unity in diversity. It is because the model of the Islamic caliphate in the golden age of Muslim community cannot be forced nor implemented in Indonesia, due to the complex backgrounds of Indonesian society (Lufaefi, 20I7: 73). Thus, Indonesian plurality has often been taken for granted to be a modality of Indonesia to promote tolerance among different religions.

I7 is a compilation of Islamic law based on Qur'an and Sunnah that regulate the way of Muslim life At the beginning of forming the Indonesian state, Some Muslim groups called for an Islamic state (Negara Islam), and others sought a compromise position, suggesting that the preamble of the constitution affirm the obligation of the state to apply Shari'a among Muslims (the so-called seven words clause) (An-Naim, 2008: 224).
A recent case on religious intolerance was depicted in Meliana's case in Tanjung Balai, Medan, North Sumatera. The court recently punished her with one year and six months in jail for her mistakes. It even caused a riot in Tanjung Balai. She was reported because of the Islamic religion defamation for her protest to the azan, a call for Muslim prayer. After two years, the judge considered that she was legally and convincingly violated article 156 of the penal code (KUHP/Kitab Undang-Undang Hukum Pidana) on her protest to azan volume in her neighborhood. ${ }^{18}$ Taufiqurrahim (20I7), in his article, argues that riot in Tanjung Balai, Medan was not merely about violence inside the case, but also a background of social motive. The complaining of azan sound from one of Buddhism believer became a reasonable justification for some Muslims to attack Vihara. ${ }^{\text {19 }}$ On the other side, it was also a case of noise pollution in terms of the ecological perspective, which impacted on religious tolerance (Taufiqurrahim, 2017: 53I). In fact, after the case of Meliana rose up to the national level, discussion about noise pollution caused by religious activities became significant. To what extent can the voice, noise, and technology support religious activity and religious preaching in public space, whereas it is an equal place for all religious believers? Public and private religious spaces became the central

I8 See the news on Meillina punishment by the judge in the court after two years in online news: https://nasional.tempo.co/read/III9663/ini-kronologi-kasus-penistaan-agama-meiliana-di-tanjung-balai/full\&view=ok. Accessed on 24 August 2018.

I9 Vihara is a monastery where Buddhists monks live in it. 
discussion in this article because it can be both the source of conflict and source of harmony at the same time.

The Indonesian government, through the Ministry of Religious Affairs, has regulated a policy regarding using the technology of speakers for azan, reciting al-Qur'an religious activity and ceremony, etc. This regulation somehow becomes like a part of the state's involvement in preventing the riots among religious believers for occupying the public spaces. What happened in Tanjung Balai, Medan shows that negotiation among different religious believers was neglected, and defamation of religion became a reasonable justification for attacking others. Moreover, the relationship between minority and majority could sustain the hegemony of the majority, in this case, was Muslims attacking Buddhist Vihara. Therefore, a lesson learned from Meliana and Tanjung Balai riot cases are that managing tolerance among different religious believer does not merely rely on the regulation on the physical space (house of worship), but rather negotiation on non-physical public space such as a religious sermon, azan, bell ringing, and the others.

In her study about religious intolerance, Febbinawati (2015) mentioned that riots or conflicts among different religious believers were based on building permit of a house of worship. She found that conflicts between Muslim and Christian were caused by Christians who built their house of worship as their wish and neglecting government decision (Febbinawati, 2015: i). The physical building of a house of worship such us Church, Mosque, and others tend to add the conflicts if not equipped with building permit and houses of worship regulation. The case of Church Yasmine in Bogor depicted how unpermitted building, which used as a church, became the source of conflict between Muslim as majority and Christian as a minority. Although there were several reasons behind this conflict, the notion of physical space as a source of conflict sounds more reasonable. That is why the discussion on building tolerance among religious believers in Indonesia cannot be separated with the two dimensions, on physical and non-physical spaces, as a public place for all. Understanding, negotiating, and accepting other religious activities in common space are needed in order to sustain harmony in religious diversity. Space in this essence plays an essential factor in sustaining the peace or threatening a harmony, with escalating the riots or conflicts regarding who has the right to occupying the spaces.

Therefore, to overcome those unfortunate situations, we have to look back and implement the positive narratives about tolerance. Our Pancasila. ${ }^{20}$ As our ideology must be implemented in such a way, fitting with the millennial generation. It is not only material delivered in the class, seminar, or discussion, but also it is practiced in the daily life of all Indonesian citizens. In other ways, the next generation of Indonesian must see the life of Indonesian tolerance as practiced in smaller scopes. In line with Prabowo (2016) argumentation stating that Indonesia is well known for its religious citizens, our society needs an internal strengthening for the sake of solidarity and sustainable peace. Then, strengthening religious life for religious tolerance and plurality must be committed and executed by all parts of Indonesia citizens (Prabowo, 2016: 25).

This article discusses the negotiation of space among religious believers and attempts to preserve tolerance and maintain a harmony of life in Indonesia. Most of this article, however, is to provide a counter-narrative to Indonesian harmony by providing a positive story of religious tolerance and harmony. It also examines the grassroots actors in building peace and maintaining harmony between the religious leader and religious believers. In essence, how the ideology "Pancasila" in the daily life is practiced in sustaining tolerance, peace, and harmony community will be presented in this article through narratives of Pancasila village or Kampung Pancasila, and other similar stories. This article also fills the gap in the studies about

20 Pancasila is a philosophical foundation of the state, a way of life, national ideology, and ligature (unifying factor) in the national life of Indonesia state (Latif, 20II: 4I). It consists of five basic principles: Belief in the one supreme God; justice and civilized humanity; The unity of Indonesia; The democracy led by understanding wisdom among honorable representatives from the parliament house; and social justice for all of the people Indonesia. 
religious tolerance, which have emphasized space (physical and non-physical) negotiation in order to maintain Indonesian peace and harmony in religious diversity.

\section{METHODOLOGY: PRIMARY DATA, SECONDARY DATA, AND DATA COLLECTION METHOD}

Research is a process of steps used to collect and analyze information to increase our understanding of a topic or issue. This process consists of three mains steps; pose a question; collect data to answer the question; and present an answer to the question (Creswell, 20I6: 3). This paper is qualitative research, conducted to find the answers to the questions. The main question proposed here is how the tolerance practiced in Balun, Lamongan? Then, is there negotiation in implementing those practices of tolerance? Qualitative research methods were used, since the purpose of this research was to get a description of the practice of tolerance in Balun, Lamongan. The data of this research was based on in-depth interviews with key informants in Balun, Lamongan, and the literature review.

In order to collect the primary data, we conducted in-depth interviews with key informants, using an interview guideline. The interviews with a village leader, a religious leader, and a local resident were conducted to get the primary information on the issue of tolerance practices in Balun, Lamongan. Meanwhile, an observation of the site of tolerance in Balun, Lamongan was also conducted during the field data collection in May 20I8. The purpose of observation to the field is mainly to get the depiction on tolerance practices, especially in physical spaces. We observe several physical spaces in Balun, Lamongan such as houses of worship (Mosque, Church, and Pura/temple), cemetery, and other Balun neighborhoods.

Besides, the secondary data was also collected to support the primary data in the period of data collection. The secondary data consisted of books and journal articles about Balun, pictures of Balun village, and a documentary profile movie of Balun village. We collected a documentary profile movie of Balun created by the young generation of Balun in describing the Balunese practices of tolerance supported by the leaders. It helped us as the researchers in analyzing the context regarding the issue of space negotiation in Balun, Lamongan.

\section{MAINTAINING HARMONY IN THE GRASSROOT LEVEL}

Besides the story of Balun Village as Pancasila Village, the stories of intra- and interreligious collaborations and sisterhoods are easily found in several places in Indonesian regencies. As well-illustrated by Sumanto al-Qurtuby (2012) about the stories of inter and intra-religious harmony in Wonosobo Regency where Shiites, Ahmadis, followers of Islam Aboge, a Javanese form of local Islam, as well as adherent of Christianity, Buddhism, Hinduism, and local beliefs, have lived peacefully and tolerantly for years with mainstream Muslim majority (Qurtuby, 2012: 150). The peaceful and tolerant community in Wonosobo cannot be separated from the leaders' influence in maintaining this intra- and interreligious harmony. The Wonosobo Regent emphasized on a mutual relationship among different religious adherents and did not discriminate between majority and minority communities. All of Wonosobo residents, regardless of their beliefs, must be fulfilled in terms of their rights as Indonesian citizens, in order to preserve the peace and harmony, as said by Arif, the Wonosobo Regent (Qurtuby, 2012: 150). Therefore, the existence of minorities groups such as Shiite, Ahmadis, Islam Aboge, Adherent of local belief in Wonosobo is not a source of conflict, since they all preserve the harmony and peace of life.

Moreover, as Sumanto al-Qurtuby (20I2) also depicted the situation in Semarang, about how people in the grassroots level play their role in preserving and maintaining harmony and peaceful life. An interreligious group "House of Peace (Pondok Damai)" was built as an informal group, gathering for peace and friendship, and the members are mostly the youth (Qurtuby, 2012: 152). This occasion is not merely to create an alliance, but also in order to preserve the peace among youth. In another location, the 
positive narrative about Muslim-Christian harmony was found in Jepara, Central Java. In the districts of Pekoso and Tempur, both Muslim and Christian communities work together for everyday affairs and religious affairs (Qurtuby, 2012: I52). Christians visit their Muslim brothers and sisters during Eid al-Fitr, and Muslims visit their Christian brothers and sisters on Christmas. It creates a peaceful society and exists based on tolerance among these different religious believers. Thus, the space of tolerance takes place not only on daily interaction and daily affairs such as Kerja Bakti or Gotong Royong. ${ }^{2 \mathrm{I}}$ However, also in religious activities and religious celebrations, such as Eid al-Fitr, Eid al-Adha, Christmas, and so on.

This paper, which takes the case of Balun as Pancasila Village, supports the idea of Qurtuby in the important role of grassroots actors in preserving tolerance among different religious believers. To take action in the peacebuilding agenda is not the responsibilities of the leaders, religious leaders, and activists, but also grassroots actors, such as ordinary people who interact with each other daily. They have to negotiate the space in their community to preserve tolerance and maintain the peace of life where people live in harmony. The peace in the society cannot be preserved and is vulnerable to conflict if the society problematizes the space and have the authority to occupy that space. Therefore, as depicted in positive stories of tolerance in several places in Indonesia above, space became the central issue in stabilizing and preserving peace, in order to create harmony among different religious believers.

\section{A SHORT HISTORY OF BALUN VILLAGE: TOLERANCE AND HARMONY AMONG DIFFERENT RELIGIOUS BELIEVERS}

Balun is a small village located in Lamongan District. It has become famous with the nickname "Desa Pancasila" or "Pancasila Village," where Pancasila's values are embedded and practiced

2I Kerja Bakti or Gotong Royong is a form or model of working together without payment for mutual benefit or purpose (See the definition at Indonesian online dictionary: https://kbbi.kemdikbud.go.id/entri/kerja\%2obakti. Accessed on 24/7/2019). as daily life by Balun community. This village is regarded as a miniature of Pancasila because of tolerance among Balun villagers with three different religious adherences. There are three main religions in Balun: Islam, Christianity, and Hinduism. Although surrounded by religious differences, people of Balun live in harmony and peace.

According to geographical location, Balun Village boundaries as follows:

I) North: Ngujungrejo Village

2) East: Gedongboyo Untung Village

3) South: Sukorejo Village (Lamongan city)

4) West: Tambak Ploso Village

The total population of Balun Village is around 4.952 people in the last year 2017 (BPS Lamongan, 2018: 27). The specification is as follows:

I) Man: 2.488 people

2) Woman: 2.464 people

Regarding religious diversity, people of Balun Village can be classified into three main religions:

I) Islam: 2.809 people

2) Christianity: 848 people

3) Hinduism: 295 people (BPS Lamongan, 2018: 78).

Balun Village consists of two regions, the Balun region, and Ngangkrik region. People of Ngangkrik are all Muslims, while People of Balun consists of three religion, as mentioned above (Sutikno, 20I6: 27).

The history of tolerance among Balun Villagers can be traced back from the existing three houses of worships in Balun. There are a mosque, a church, and a pura (temple) in the middle of the village and situated nearby. The mosque as the house of worship for Muslim in Balun is located in front of the Balun field. Moreover, across the field, there is a church for Christians. Meanwhile, pura (Temple) as the house of worship for Hinduism believers is located around the 500-meter west side of the Mosque. For the details of houses of worship, see the pictures below: 

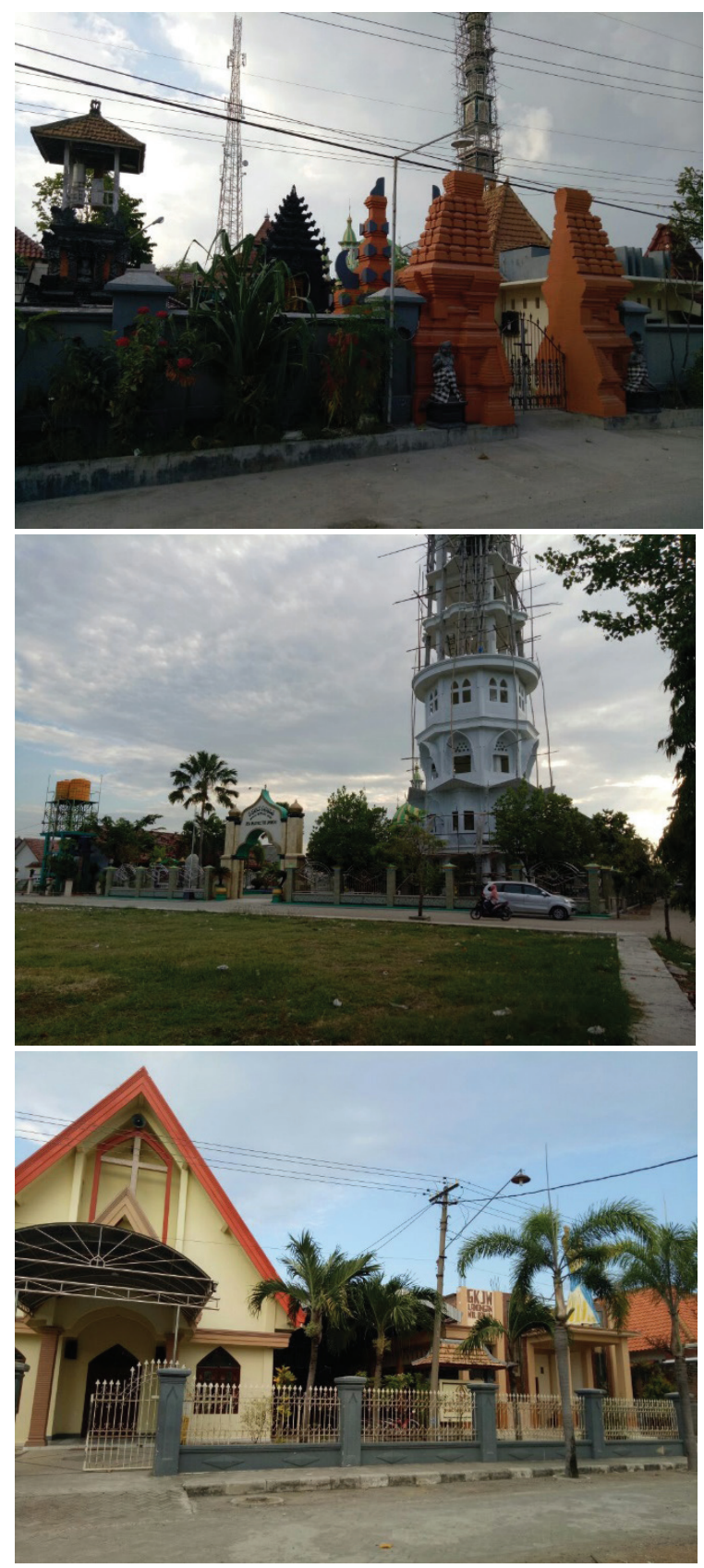

Pictures I. Location of Mosque, Church, and Pura (Temple) in Balun Village

Within these locations of houses of worship in Balun, it can be assumed that Balun villagers negotiate the spaces in their village for building different houses of worship near to each other. It is impossible to build houses of worship near to each other if strong tolerance and negotiation among the villagers are not regarded as the bases. Meanwhile, the existence of mosque, church, and pura somehow depicts the diversity and plurality of Balun villagers that consist of Muslim, Christians, and Hindu. Thus, differences of religious believers in Balun can be traced from the history propagation of religion in Balun (Sutikno, 20I6: 28). In the early history of Balun, Islam was the religion introduced by Mbah Alun and embraced by the villagers. Then, Christian and Hinduism were introduced to the villagers after the I965's crisis. In I967, Pak Batih, a Christian soldier, was assigned as the village official to fill in the government's absence in the village. He was the one who introduced Christianity to Balun villagers, with the help of his friend and pastor to baptize the new adherents. Also, in I967, Mr. Tahardono Sasmito, a Hindu figure from Plosowayuh, introduced Hinduism to Balun villagers. Christianity and Hinduism as new religions in Balun attracted some villagers to be the adherents because of its teaching. So, embracing new religions in Balun was caused by personal interests, without coercion. Therefore, Christianity and Hinduism developed gradually in Balun. ${ }^{22}$

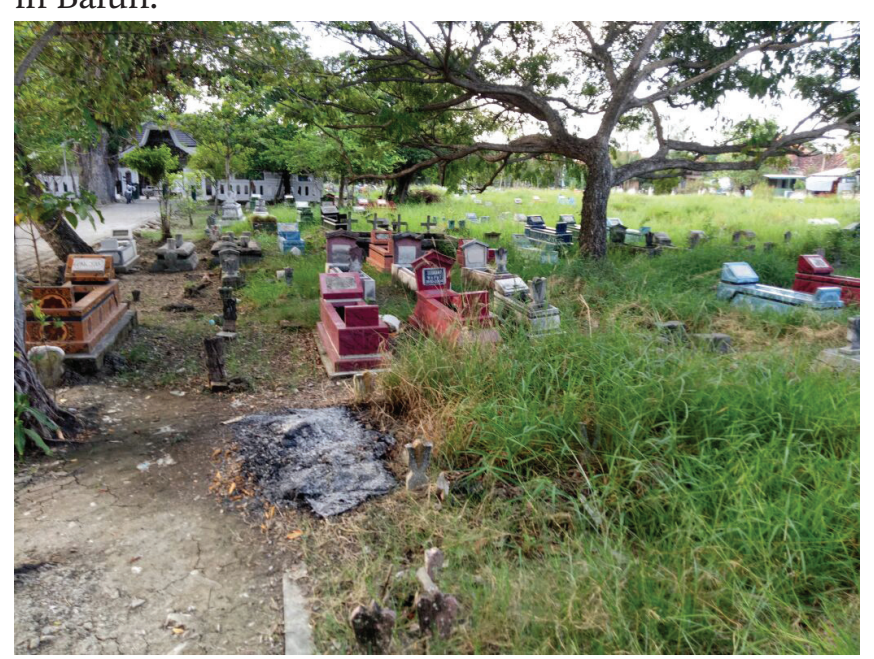

Picture 2. Cemetery in Balun Village (Muslim, Hindus, and Christian tomb)

Another site of tolerance in Balun, Lamongan is the village cemetery. If cemetery in other districts is often differentiated between cemetery for Muslim and others, but it does not happen in Balun, Lamongan. The cemetery in Balun is a common cemetery for all villagers, regardless of their religious backgrounds, whether they are Muslim, Christian, or Hindu. However, after the Christian community-owned land for their own cemetery, Christian burials then

22 The history of Balun, Lamongan, East Java. See on the internet online: https://beritagar.id/artikel/laporan-khas/belajar-pluralisme-dari-balun (accessed on 9/4/2018). 
take place in other places. This occasion of separation is only to simply for a place for burial. It is also about the rules. While the Christian tombs face to the east, Muslim and Hindus tombs face to the west. Although the Christian community has owned their cemetery recently, the old tombs in the common cemetery are not relocated to the new cemetery, as shown in the picture below. Nowadays, Muslim and Hindus cemeteries are still located in one location, the common cemetery. This cemetery of Muslim and Hindus is located in between Miftahul Huda Mosque, and Gereja Kristen Jawi Wetan (GKJW). ${ }^{23}$ Also, Pura Sweta Maha Suci. According to Juru Kunci of the cemetery, chief of Dusun $^{24}$ and some villagers, bodies of the Hindu adherents in Balun are not burnt but buried. They are buried in the common cemetery of Balun, along with the Muslim tombs. ${ }^{25}$ See the picture below that depicts the situation of Balun's cemetery where Muslim, Christian, and Hindus burials are in one location.

In the social life of Balun villagers, death is one of the topics where tolerance is practiced, and harmony is seen. If we look at the picture above, the Muslim, Christian, and Hindu tombs are located in one cemetery without separated by a fence or other separators. Thus, it shows how Balun people are not only tolerant of life, but also on death. Furthermore, if one of the Balun villagers passes away, all villagers will pay respect and take the body to the grave regardless of their religions. People of Balun join the burial ceremony and the religious. Chief of Dusun Balun told to us on how people of Balun treat to the deceased:

23 GKJW (Gereja Kristen Jawi Wetan) is the alliance of regionally-based churches in East Java that declared the first time on II December 1936. GKJW has determined its existence is only limited to East Java. Therefore, there will be no GKJW outside East Java, and it is relevance to GKJW's governance and procedure. See on the internet online: https://gkjw.or.id/tentang-gkjw/sejarah/. Accessed on $24 / 06 / 2019$.

24 Dusun is a territory within a village (desa). A village consists of several Dusun which is led by a chief of Dusun. Meanwhile, a Dusun consists of several citizens association or RW (Rukun Warga) and neighborhood association or RT (Rukun Tetangga). The chief of Dusun has a task to help the duty of Village's chief.

25 Sujatmiko. 20I7. Belajar Pluralisme Dari Balun. See on the internet online: https://beritagar.id/artikel/ laporan-khas/belajar-pluralisme-dari-balun. Accessed on 9/4/20I8.
"Usually, if someone dies in Balun, one neighborhood association or RT (Rukun Tetangga) will dig the grave without seeing the deceased as Islam, Christian, or Hindu. It is treated the same as one neighborhood association, or RT (Rukun Tetangga) will dig his grave. The difference is only on religious processions. For example, the deceased of Muslim is prayed at the mosque while the Christians and Hindus are waiting outside. Likewise, if a Christian deceased has a religious procession at home or church, yes Muslims and Hindus will wait outside. After the religious procession, all of Balun villagers will escort the deceased to the grave as the form of honor. ${ }^{26}$

\section{The Role of Elites In Maintaining Harmony And Peace In Balun}

On another side of peace, we cannot neglect the role of the elite in maintaining peace. What we meant about the elites in this discourse, as Lederach classifies, are top leaders, middlerange leaders, and grassroots leaders. The elite's involvement in maintaining peace and harmony is a great contribution. It is shown by Abbas (20I6) on his analysis of the role of elites in Manado in maintaining peace (Abbas, 2016: 9). The elites in a community play their role in managing the harmony by implementing their religious values and Pancasila ideology. They see the importance of peace for the community, with tolerance as the main basis.

The elites of Balun, Lamongan in this issue are classified in two area. I) village bureaucrats, such as head of the village 2) religious leaders such as $\mathrm{kyai}^{27}$, pendeta ${ }^{28}$, and pandita. ${ }^{29}$ The detail on how elites perform their contribution in preventing conflict and maintaining peace and harmony among Balun people are found in the narratives below.

$26 \quad$ Interview with Chief of Dusun Balun, $6^{\text {th }}$ May 2018. $27 \quad$ Kyai is a title given by the community to an expert in Islam who own or lead a pesantren (Islamic Boarding School) and teach classical Islamic books to the student. In Central Java and East Java, ulama' (Islamic scholars) who lead pesantren called Kyai. However, in the recent era, there were prominent ulama' (Islamic scholars) in the society get a tittle of Kyai even though did not lead or owns a pesantren (Islamic Boarding School) (Dhofier, 20II: 93).

28 Pendeta is a religious leader in Christianity or Catholicism. See the definition in https://kbbi.kemdikbud. go.id/entri/pendeta. Accessed on 24/7/2019.

29 Pandita, a holy man in Hinduism. They are a religious leader and usually lead Hindus ceremony in a small or big scale. 


\section{The Role Head of The Village}

The existence of local elites in the bureaucracy of Balun village supports the idea of tolerance among its villagers. The head village of Balun realizes the diversity and plurality of religion and its harmony among different religious adherences. Therefore, in several occasions and official village agenda which involves three religions in Balun, he always opens and greets in three salutations; assalamuailakum wr.wb. For Muslim, salam Sejahtera for Christians, and Om Santi, Santi for Hindu. As narrated by one of the chiefs in Dusun Balun in the interview, "So, in our official village agenda with three religions such us official village meeting, the head of the village greets the audience with three salutations.30

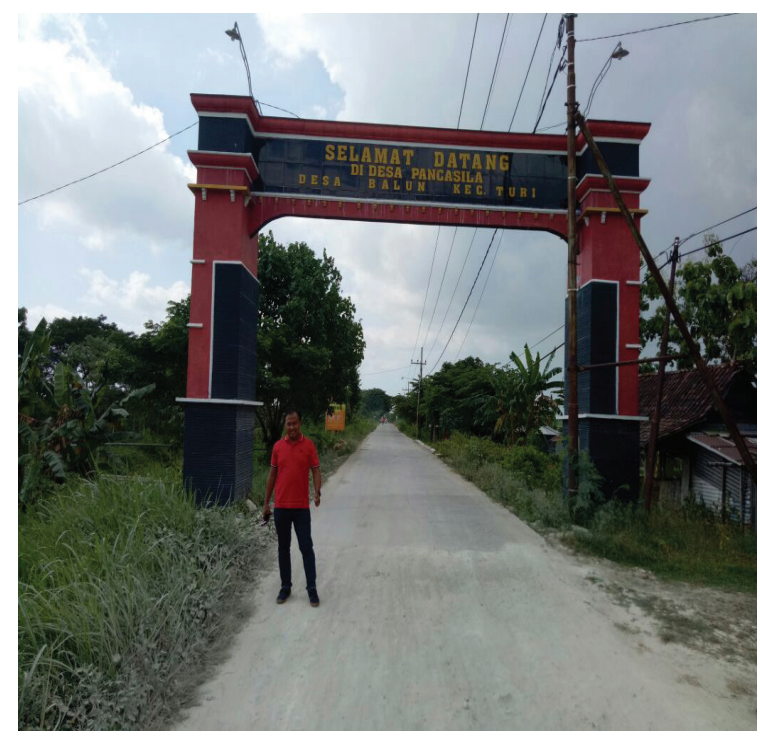

Picture 3. Entrance gate of Balun "Desa Pancasila"

Meanwhile, the bureaucrats of Balun also realize the special identity attached and given by the public as Desa Pancasila. Then, several agenda and monument were built in order to promote the title as Desa Pancasila, such as building entrance gate and video profile of Balun. Others gave the title of Desa Pancasila (not by Balun villagers themselves) and embedded time by time through history after seeing the harmony among different religions in Balun. Therefore, the entrance gate of Balun Village with the writing "Desa Pancasila" was built recently to support the Balun Village identity.

Moreover, the head of Balun Village also produces a short video containing Balun village

Interview with Chief of Dusun Balun, $6^{\text {th }}$ May 2018. profile. This video profile describes the situation of harmony and peace among the three religions in Balun. Harmony and peace are also shown in the negotiation of physical space of houses of worship and the religious activity among Muslim, Christian, and Hindu. The video shows how the religious leader and its followers live together and support each other's religious activity. Muslim supports and helps their Christian brothers and sisters during Christmas and Hindu brothers and sisters during Waisak ceremony. Likewise, Christian and Hindu help Muslim brothers and sisters during Eid al-Fitr, Eid al-Adha, and other religious ceremonies. The idea of making a video profile came from the young generation of Balun village. The head of the village accommodated and executed the idea as a part of Balun promotion as the tolerant village and role model for Indonesian harmony.

\section{The Role of a Religious Leader in Balun}

Tolerance in Balun is also about the role of religious leaders from Islam, Christianity, and Hinduism. Sutikno (20I6), in his study, talked in detail about the role of each religious leader and their thought about harmony, peace, and religious faith, and the relation with other religion. Tolerance in Balun is a reality that has been constructed a long ago. It is also as manifestation, depicted by the relation among the religious leaders and society (Sutikno, 2016: 92). Therefore, there are spaces where tolerance is internalized within Balun society. First, family as the core of children education about tolerance. Many families consist of members with different religions, such us Muslim father, Christian mother, with Hindus child. Thus, tolerance in Balun is not only discourse but also practice in the early stage. Second, school as a place for formal education where the children in Balun study and learn the discourse about tolerance and the teaching of their religions about tolerance and relation with other religions. The last part is the social realm of activity, where people of Balun are interconnected on social agenda, such as a wedding, independence ceremony, and others. All villagers help each other and support the events regardless of the religious background of the host. For instance, during Eid al-Fitr or Eid al-Adha prayer, youths 
of Christian and Hindu became the guard. The same thing happened during Christmas and Hindu festivals. ${ }^{3 \mathrm{I}}$

\section{SPACE NEGOTIATION IN BALUN, LAMONGAN: AN EFFORT IN MAINTAINING HARMONY AND PEACE}

This chapter focuses on the discussion of space as public and private area where religions meet. Space as public property is often occupied by the majority who take a role as the ruler. Meanwhile, the minority faces difficulties to build their house of worship, a place where they can perform their duty as religious believers. Furthermore, the Indonesian government's policy on building houses of worship often favor the majority; in this case, it is Islam. This policy is utilized by the perpetrator to attack other houses of worship and religious groups. To some extent, if we neglect this condition, it will threat to Indonesian unity where diversity is the basis.

It is important to note that best practice of tolerance among Balun villagers with three religion is not merely about accepting the religious differences but also dealing with public space where religious activity should be permitted equally. How do Muslims who use speakers regularly for azan and Puji-pujian, deal with their Christian friends on Sunday afternoon mass and with Hindu friends who on Thursday nights do their sembahyang (prayer) ritual. In Balun, the Muslim as the majority has the privilege to use the speaker in their house of worship to call for prayer (azan) five times a day. After azan, the Muslim conduct puji-pujian, which consists of shalawat in order to wait for the arrivals of worshippers. However, their azan and puji-pujian are also heard by other different religious friends (Christian and Hindu) in Balun.

Nevertheless, it is also situated on Sunday afternoon during Christian mass at the church or Hindu prayers on Thursday

3I Interview with Chief of Dusun (Kadus) Balun, $6^{\text {th }}$ May 2018. Chief of Dusun is a chief who became headmaster of territory under a village administrative. He or She has a duty to help Chief of Village in managing certain territorial within a village. night. How do the Balun villagers deal with it? According to Balun villagers, this situation is not a serious matter since they are able to discuss the solution to this issue.

The presence of houses of worship of three religions in Balun, Lamongan is a site to analyze the practice of tolerance. Three houses of worship in Balun, Lamongan were built near to each other. In Indonesia, building a house of worship is regulated in the joint regulation of Minister of Religious Affairs and Minister of Internal Affairs Number 9 and 8, the Year of 2006. The prerequisite to building a house of worship must be fulfilled based on the administrative and technical administrations. On the other side, if we look at the regulation on house of worship issued by the government, we could not find any regulation about the distance for one house of worship to another. It depends on the society's informal regulation where the religious leaders, society leaders, and elderly leaders agree upon the locations of houses of worship location. Therefore, the acceptance and negotiation among different religious believers in Balun, Lamongan takes place and is depicted well in the spaces where these houses of worship were built. As a result, the nearby location of houses of worship became a beautiful scenery, where different religious adherents exist side by side.

Brodin (2004: 196) defines public spaces as non-private spaces outside the household; often, they are places like squares or streets, but they can also be empty spaces, which do not invite public life. Meanwhile, in Arendt's words, public space suggests space emerges wherever and whenever "men act together in concert." On this model, public space is the space where freedom can appear (Benhabib, I992: 93). However, Habermas used a different term, which is the public sphere. In Habermas model, the rigid separation between public and private is justice and the good life, need and interest, values, and norms (Benhabib, I992: I04). Despite the differences between the definitions and models proposed by these scholars, the focus on public spaces requires equality, freedom, and accessibility of spaces by all citizens for creating a quality of life. 
The concept of public space is also debatable since it starts with the importance of wellplanned, maintained, and designed public open spaces and their effect on the quality of life. It refers to many different qualities, conditions, and practices (Robbinson, 2008: I40). Since the design of public space is to improve the quality of the citizens' life, building houses of worship must consider this concept. The well-planned houses of worship can support the practice of tolerance and harmony. In essence, the existing mosque, church, and pura (temple) in Balun, Lamongan was well designed with the surrounding field as the social space in the village. In the field, peoples with different religions could access this area and practice tolerance to each other during the process of a certain religious ceremony or ritual. The situation in Balun, Lamongan is in line with Brodin's (2004) argument that the configuration of the space influences a human relationship. Depending on the configuration, space can encourage solitary movement or collective activity (Brodin, 2004: 212). The existence of houses worships located near to each other influences the Balun villagers' relationship that they have the custom to tolerate their neighbors.

Meanwhile, Robbinson (2008) suggests the concept of social space, rather than public or private space. He suggests it because of the inclusiveness of this concept. It refers to those spaces that we use as groups that involve collectiveness -communal, cooperative, or conflictive-activities, exchanges, and practices. By using the term of social, we avoid the baggage of concepts of public or private (Robbinson, 2008: I44). Here, we can argue that the field in front of the houses of worship in Balun, Lamongan is a social space where all citizens' activities, including religious activities, are held by the community. They work together and help each other in conducting religious ceremonies. Besides the concept of public spaces, the social space concept also helps us in portraying the practice of tolerance among Balun, Lamongan residents.

Meanwhile, negotiation about the space as public emphasizes on not only the physical location but also the religious rituals practiced in the houses of worship and the public space. In Balun, the close distance between mosque, church, and temple (pura) becomes an interesting aspect to portray tolerance. However, it also raises questions about how tolerance pattern is practiced by three different religious adherences (Sutikno, 20I6:I06). Religious practices, such as rituals and prayers as private activities of religious believers are practiced in the houses of worship, according to the specified time and often intersect each other when it comes to the public. For instance, azan (call for prayers) for Muslim, which is done five times daily often intersect the time for Christian or Hindu during their rituals at their houses of worship. If negotiation and compromise among each other about these sensitive issues on religious rituals are not agreed upon, conflicts and riots may occur. However, what we see in Balun, Lamongan is the best example of tolerance with negotiating and compromising the rituals practiced in private houses of worship and rituals of others in public spaces. Balun villagers understand what should be practiced in public and private, regarding their religious practices and rituals.

In Balun, Islam is the first religion. Then, after G30S PKI, Christianity, and Hinduism entered to Balun since around 1967 or 1968. That is what I heard from the elders if I am not mistaken. Christianity and Hinduism entered and were accepted by the people of Balun. Finally, until now, Islam is still strong, and Christianity and Hinduism are more developed without any friction among each other's believers. ${ }^{32}$

Then, the narrative on preserving harmony and peace is depicted in the story about a message delivered by the religious leader or kyai who was invited to deliver sermons in certain religious agenda or pengajian in Balun, Lamongan. Head of Dusun Balun told us:

"If there is a religious sermon and a Kyai for outside Balun invited, we always inform him that Balun consists of three religions. We must inform them that, to prevent the people from offensive sermons. The sermons are favorable about general issues and for the good sake of ummah. We have to be careful in maintaining and keeping our harmony of life." ${ }^{33}$

32 Interview with Chief of Dusun Balun, $6^{\text {th }}$ May 2018. 33 Ibid 
From this story, an effort to maintain peace and harmony in Balun, Lamongan is also conducted by elites. The elite bureaucrats of Balun inform the elite of religious leaders that Balun villagers consist of people from different religions. Therefore, the essence of sermons must suit with this reality and respect other religions in order to reduce or avoid conflict. By doing this, sermons delivered by local kyai or invited kyai in the religious festival can support and strengthen the tolerance among religious believers in the village. Therefore, harmony in Balun is internalized by the religious teaching and also implemented in their daily life.

\section{CONCLUSION}

Indonesia, as a multi-religious nation, must be realized by all Indonesian citizens. Therefore, tolerance must be preferred in order to maintain and sustain harmony and peace. As described in the discussion above, it can be concluded that tolerance in Balun, Lamongan has been constructed by and internalized in Balun villagers for a long time. Tolerance in Balun is depicted in the houses of worship that are located near to each other. It indicates that the physical space in building a house of worship involves negotiation among the adherences.

On one side, the non-physical space tolerance occurred in the Balun is reflected in how each religion accommodates other religion's interest when they intersect. Muslims and Christians, through their religious leaders, negotiate and solve the issues regarding the religious activities since they become public and are intersected with other religion's activities. For instance, the moment where the Christian's Sunday evening rituals coincide with the Muslim's Maghrib call for prayer and Qur'an recital in Mosque. On the other side, the tolerance in Balun is also not only practiced on life, but also on the burial ceremony. The cemetery of Balun village portrays the tolerance among villagers. The Muslim and Hindu graves are located in one location, since they face the same direction, to the west while the new Christian cemetery is in other location.

Nevertheless, the old Christian tombs are not relocated to the new Christian cem- etery. That situation illustrates that tolerance among religious adherences in Balun has been internalized and practiced in daily life and also concerning the dead. It is difficult to do in many other areas because usually the cemetery must be differentiated in terms of the location, and sometimes it can lead to tension.

In sum, this article has provided factual narratives of tolerance among different religions in Indonesia. The tolerance must be sustained and maintained with the negotiation of space. It is where the physical and non-physical spaces are discussed to find common ground. The stories of interreligious harmony have happened in many places in Indonesia, and they should be promoted. Indonesia, with the diversity of religions and beliefs, should refer to these narratives where different religious believers live side by side with tolerance among each other in the public space. The spaces which belong to no one should be negotiated together to create peace and harmony. Space should not be occupied only by one group while neglecting the others because it will lead to intolerant acts and discrimination. In the practices, tolerance among religious believers begins with the negotiation of space, physically and non-physically. These stories of interreligious tolerance must be circulated and embedded to the next generation as early as possible because it can eliminate the hatred to other religious believers and so they can live together side by side in peace and harmony. In sum, tolerance is not only lip service in an Indonesian discourse, but it is implemented and practiced in daily life.

\section{REFERENCES}

Abbas, M. R. (2016). Peace in the Midst of Violence: Analyzing the Role of Elites in Preserving Peace and Harmony in Manado. Indonesian Journal of Islamic Literature and Muslim Society, I(I), I-28. http://dx.doi.org/Io.225I5/islimus. VIiI.2I4

An-Naim, A. A. (2008). Islam and the Secular State: Negotiating the Future of Sharia. England: Harvard University Press.

Belajar pluralisme dari Balun. (20I7, Juni 3). https://beritagar.id/. Retrieved from https:// beritagar.id/artikel/laporan-khas/belajar- 
pluralisme-dari-balun. Accessed on 9 April 2018.

Benhabib, S. (1992). Models of Public Space: Hannah Arendt, the Liberal Tradition, and Jurgen Habermas. In Situating the Self: Gender, Community, and Postmodernism in Contemporary Ethics. Cambridge: Polity Press. pp. 89-I20.

BPS Lamongan. (2018). Kecamatan Turi dalam Angka 20I8. Lamongan: Badan Pusat Statistik Kabupaten Lamongan.

Brodin, L. J. (2004). Illusion of Freedom. Dissertation submitted to the Faculty of the Graduate School of the University of Maryland.

Creswell, J. W. (2016). Educational Research: Planning, Conducting, and Evaluating Quantitative and Qualitative Research. $4^{\text {th }}$ Edition. Boston: Pearson.

Dhofier, Z. (20II). Tradisi Pesantren: Studi Pandangan Hidup Kyai dan Visinya Mengenai Masa Depan Indonesia. Jakarta: $\mathrm{LP}_{3} \mathrm{ES}$.

Febbinawati, F. (2015). Potensi Konflik Antara Penganut Agama Islam dan Kristen: Studi Kasus Pendirian Rumah Ibadah di Desa Sungai Sirih, Kecamatan Singingi, Kabupatan Kuantan Singingi. Skripsi Si Jurusan Perbandingan Agama. Riau: Fakultas Ushuluddin, UIN Sultan Syarif Kasim Riau.

GKJW. (n.d.). Tentang GKJW. Retrieved from: https:// gkjw.or.id/tentang-gkjw/sejarah/. Accessed on 24/06/2019.

Ini Kronologi Kasus Penistaan Agama Meiliana di Tanjung Balai. (2018, Agustus 23). Tempo. Retrieved from https://nasional.tempo.co/ read/III9663/ini-kronologi-kasus-penistaanagama-meiliana-di-tanjung-balai. Accessed on 24 August 2018.
Kemdikbud (n.d). KBBI Daring. Retrieved from https://kbbi.kemdikbud.go.id/entri/kerja\%20 bakti. Accessed on 24/06/2019.

Latif, Y. (20II). Negara Paripurna: Historisitas, Rasionalitas, dan Aktualitas Pancasila. Jakarta: PT. Gramedia Pustaka Utama.

Lufaefi, L. (20I7). Rekonstruksi Jargon Formalisasi Syariat: Upaya Menjaga Persatuan dalam Bingkai Keberagaman. Al-A'raf : Jurnal Pemikiran Islam dan Filsafat, I4(I), 73-90. DOI: I0.22515/ ajpif.vi4iı.805

Prabowo, M. N. (2016). Kerukunan Umat Beragama Sebagai Cita-Cita Etis (Sebuah Tinjauan Etika). Sosiologi Agama; Jurnal Ilmiah Sosiologi Agama dan Perubahan Sosial, Io(I), 2I-42. https://doi. org/Io.I442I/jsa.20I6.IoI-02

Qurtuby, S. A. (20I2). Reconciliation from Below: Indonesia's Religious Conflict and Grassroots Agency for Peace. Peace Research, 44/45(2/I), I35-I62.

Robbinson, E. (2008). Rethinking Public Space: a New Lexicon for Design. Urbani izziv, vol.i9, No.2, 2008.

Sutikno. (2016). Satu Dusun Tiga Agama: Konstruksi Toleransi Keagamaan di Dusun BalunLamongan. Lamongan: Pustaka Ilalang in cooperation with Badan Perpustakaan dan Arsip Daerah, Pemkab Lamongan.

Taufiqurrahim. (2017). An Ecological View of the Religion and Noise Pollution: Does it Make Sense? In proceeding IGSSCI $9^{\text {th }}$ 9-Io August 20Io, with theme "Sustaining The Planet: Call for Interdisciplinary Approach and Engagement. Yogyakarta: The Graduate School of Universitas Gadjah Mada. 